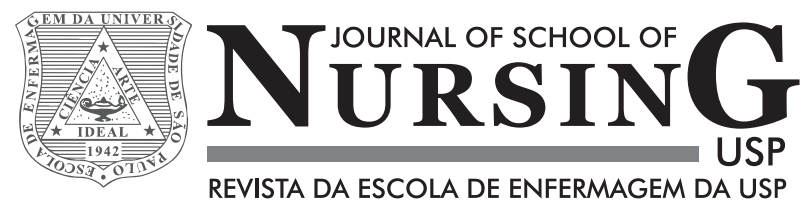

\title{
Terms of International Classification for Nursing Practice in motor and physical rehabilitation*
}

\author{
Termos da Classificação Internacional para a Prática de \\ Enfermagem em reabilitação físico-motora \\ Términos de la Clasificación Internacional para la Práctica \\ de Enfermería en rehabilitación físico-motora
}

\begin{abstract}
Danyelle Rodrigues Pelegrino de Souza ${ }^{1}$, Leonardo Tadeu de Andrade ${ }^{2}$, Anamaria Alves Napoleão ${ }^{3}$, Telma Ribeiro Garcia $^{4}$, Tânia Couto Machado Chianca ${ }^{5}$
\end{abstract}

\footnotetext{
* Extracted from the dissertation "Identificação e validação de termos de linguagem especial de enfermagem em reabilitação física motora de pacientes adultos," School of Nursing, Universidade Federal de Minas Gerais, 2012.

${ }^{1}$ Master's in Nursing, School of Nursing, Universidade Federal de Minas Gerais, Belo Horizonte, MG, Brasil.

${ }^{2}$ Doctorate student, School of Nursing, Universidade Federal de Minas Gerais, Belo Horizonte, MG, Brasil.

${ }^{3}$ Professor, Department of Nursing, Universidade Federal de São Carlos, São Carlos, SP, Brasil.

${ }^{4} \mathrm{Co}$-director of the Center for Research and Development of ICNP ${ }^{\circledR}$, Post-graduate program of Nursing, Universidade Federal da Paraíba, João Pessoa, PB, Brasil.

${ }^{5}$ Tenured Professor, School of Nursing, Universidade Federal de Minas Gerais, Belo Horizonte, MG, Brasil.
}

\section{ABSTRACT}

Objective: To validate terms of nursing language especially for physical-motor rehabilitation and map them to the terms of $\mathrm{ICNP}^{\oplus}$ 2.0. Method: A methodology research based on document analysis, with collection and analysis of terms from 1,425 records. Results: 825 terms were obtained after the methodological procedure, of which 226 had still not been included in the ICNP ${ }^{\varpi} 2.0$. These terms were distributed as follows: 47 on the Focus axis; 15 on the Judgment axis; 31 on the Action axis; 25 on the Location axis; 102 on the Means axis; three on the Time axis; and three on the Client axis. All nonconstant terms in $\mathrm{ICNP}^{\circledast}$ have been validated by experts, having reached an agreement index $\geq 0.80$. Conclusion: The $\mathrm{ICNP}^{\circledast}$ is applicable and used in nursing care for physicalmotor rehabilitation.

\section{DESCRIPTORS}

Rehabilitation Nursing; Terminology; Classification; Validation Studies. 


\section{INTRODUCTION}

Technological development coupled with the increasing exchange of information between people in a globalized world has mobilized Nursing worldwide to standardize and universalize its language in order to highlight the concepts of its practice. The clarification of this language is the most effective way to define the essence of a concept and solve relevant problems for the common meanings of terms, thereby reducing ambiguities and inconsistencies, creating ways to record and document actions, and organizing databases capable of generating knowledge and information, especially in information systems such as electronic patient records (EPR) $)^{(1)}$.

EPR is considered a formal communication vehicle between the members of the healthcare team. It enables many health professionals involved in patient care to have direct access to the registry in their respective areas. It is through this way that nurses and other professionals can share information and ensure continuity of care.

The use of a nursing classification system for clinical data recording in EPR allows the storage and retrieval of information, generating data for research on the effectiveness and efficiency of a particular procedure, enabling formal and efficient communication, contributing to the access of patient information by professionals involved in the care, and continuity and quality of care $\mathrm{c}^{(2)}$.

There are currently several nursing classification systems that represent and organize the elements inherent in the nursing process (NP), such as diagnostics, outcomes and nursing interventions. However, these systems have different structures and are subject to local cultural influences, which ultimately hinder the universal language of nurses and their adaptation to other nursing communities. Therefore, the need for developing a reference model that supports both the representation of nursing concepts and the integration of this model with other health models can be observed ${ }^{(3)}$.

When thinking of a reference model and in the absence of a universal nursing language, the International Council of Nurses (ICN) adopted a proposal in 1989 for the development of an international rating system that would meet the objectives of representing the concepts of nursing and integration with other health areas. Hence, the development of the International Classification for Nursing Practice $\left(\mathrm{ICNP}^{\circledR}\right)$ began, which is designed to be an integral part of the global information infrastructure. As such, it is an instrument that facilitates communication between nurses and with other health professionals ${ }^{(4)}$.

Since Version 1.0 released in 2005, ICNP ${ }^{\circledast}$ has become organized into a seven-axis structure: focus, judgment, action, means, client, location and time. It should be noted that from this version, the $\mathrm{ICNP}^{\circledR}$ started its development with a formal, ontological approach in order to make it consistent with other vocabularies used in health care and with existing standards for terminology development, an aspect which was considered relevant to the representation and retrieval of documentary information about the care provided by nursing their clientele ${ }^{(2)}$.
The data and the information from the nursing records can be used for planning and care management, financial forecasts, analysis of the results and policy development. As an international standard, the ICNP ${ }^{\circledast}$ provides the collection and analysis of Nursing data on health care services between populations of different countries. The data generated by the use of ICNP $^{\circledR}$ can support decision making, thus improving the safety and quality of care for patients and their families ${ }^{(2,4)}$.

In 2008, the World Health Organization included the ICNP $^{\oplus}$ as part of the Family of International Classifications, where the International Classification of Diseases (ICD) is also found. Since its inception, eight versions of $\mathrm{ICNP}^{\circledR}$ have been published: Alpha, Beta and Beta 2 (preliminary) version 1.0 (2005), version 1.1 (2008), version 2.0 (2009), the 2011 version and the 2013 version ${ }^{(4)}$. This latest version is available on the ICN website, translated into several languages, including Brazilian Portuguese (http://www. icn.ch/pillarsprograms/icnpr-translations/).

It is observed that the physical-motor rehabilitation is an important component in the health-disease process and the psychosocial care of people with disabilities. This is due to the significant increase in the number of people with chronic diseases and those that survive neurological damage, such as stroke, spinal cord injury, and traumatic brain injury. However, there is a rating system specifically dedicated to the nursing care of physical-motor rehabilitation, although the number of individuals demanding this specialized care is increasing ${ }^{(5-6)}$.

Given the above, the following question arises: What terms used by nurses when caring for adults in physical-motor rehabilitation may constitute a database for this area of expertise, to guide clinical practice and the effective registration of nursing data, regardless of its means of traditional or electronic support?

Appreciating the fact that the ICN recognizes the necessity of the existence of diagnostic subsets, nursing interventions and outcomes for specific areas of practice (ICN, 2005), this study was designed with the purpose of contributing to the construction of a subset of $\mathrm{ICNP}^{\circledR}$ concepts for physical-motor rehabilitation. Therefore, the aim of this study was to validate the terms of the special nursing language used in physical-motor rehabilitation, identified in the records of rehabilitation nurses, and mapping them to the terms of $\mathrm{ICNP}^{\circledR} 2.0$.

\section{METHOD}

This is a methodological study conducted from 2009 to 2010 based on document analysis, and applied to medical records of adult patients in the rehabilitation process admitted to the Rede Sarah Rehabilitation Hospital, Belo Horizonte-MG Unit, Brazil, for identification of terms used in the nursing records.

The place where the study was conducted is part of a hospital network consisting of nine units located in BelémPA, Belo Horizonte-MG, São Luís-MA, Fortaleza-CE, Macapá-AP, Rio de Janeiro-RJ, Salvador-BA and two in Brasilia-DF. The records are electronic, are interconnected 
and can be found in any other unit, providing the same level of care quality across the network and allowing constant inter-consultation and upgrading of programs.

The preference for this site for the development of the study was due to the use of the nursing process as a methodological care model and the use of $\mathrm{ICNP}^{\circledast}$ as a rating system to record the nursing practice in the institution.

The ethical and legal principles to be followed in investigations involving human beings were respected during research development, as recommended by Resolution No. 466 of December 12, 2012, by the Conselho Nacional de Saúde ${ }^{(7)}$. Data collection was performed after approval by the Ethics Committee on Research of the Rede Sarah Hospitals and Universidade Federal de Minas Gerais (ETIC 0376.0.203.000-10). The anonymity of patients whose medical records were searched is assured, as well as the participating nurses' validation process of the identified terms.

The process of extracting terms for nursing development occurred during the year 2009. The evolutions of nursing medical records of all patients admitted to adult wards that year were included, namely in Orthopedics (557 records), Neurological Rehabilitation (376 records), and rehabilitation of injured individuals (492 records), totalling 1,425 electronic records searched. The terms extracted from medical records were entered into a spreadsheet in Microsoft Office Excel in alphabetical order, initially totalling 827,047 terms constituting the corpus of analysis. Subsequently, repetitions were eliminated resulting in a total of 1,348 terms $^{(8-9)}$.

For the process of normalizing 1,348 terms, spellcheck and synonym analysis were performed, excluding terms that had the same meaning; terms were converted to infinitive form; standardized for gender (male or female) and number (singular or plural); terms related to procedures and medical diagnostics were excluded; and explanation of acronyms that identified some terms. Pseudo-terminological expressions were excluded, meaning "elements that occur in a casual way in the discourse, but which do not designate particular concepts, and are considered 'junk' terminology"(9). At the end of this stage, 825 terms were obtained.

In order to avoid loss of important data and because these rounds require more careful attention and effective care by those who perform them, guidelines were adopted to allow for standardization of the strategies to be used since all researchers were involved in this process ${ }^{(9-10)}$.

Next, cross mapping was performed in which the terms identified in the study were compared with the terms present in the ICNP ${ }^{\circledast}$ 2.0. At the end of this round, 599 terms in the seven axes composing ICNP 2.0 and 226 non-constant terms were identified, the latter being distributed into the structure of the seven axes, as follows: 47 on the Focus axis; 31 on the Action axis; 15 on the Judgement axis; 102 on the Means axis; 25 on the Location axis; three on the Time axis; and three on Client axis.

Each of the 226 terms underwent a theoretical definition process for which textbooks, scientific articles, dictionaries of the Portuguese language and technical dictionaries of health and nursing were used. It should be noted that this process was organized in accordance with the guidelines for conducting terminology work, according to which distinctive features should be selected that allow the concept of identification and the type of setting that best suits the profile of users, in this case, people involved in physicalmotor rehabilitation process ${ }^{(8-9)}$. To define the terms, the established rules of the $\mathrm{ICNP}^{\oplus}$ were considered: to not be circular; makes sense; exposes the essential attributes of the concepts underlying the word; avoids the use of ambiguous or unclear language; is literal and is expressed in a positive sentence, being neutral and non-judgmental. In addition, a definition cannot be too broad as to allow the words that define it to apply to more objectives than necessary; and should not be restricted as to exclude legitimate explanations of the word ${ }^{(11)}$.

The terms identified in the study were thoroughly validated, including the conceptual definition attributed to them and their respective allocations of the seven axes of $\mathrm{ICNP}^{\circledast}$ in this process. Hence, the opinion of the nurse participants of the research was requested. They expressed their degree of agreement or disagreement regarding the term, its definition and allocation on the ICNP ${ }^{\circledR}$ axis. If deemed necessary, the participant was able to write down comments or suggestions in a field of the instrument available to do so.

The Delphi technique was used in the validation process, giving group consensus about a certain subject. The group was composed of judges, meaning professionals effectively engaged in the area where for which it is developing the study. They think of the theme, and a consensus must be reached in a minimum of two rounds; if a consensus is not reached in these early rounds, as many rounds as are necessary are held.

Recent nursing research has used this method with experts for the validation of diagnoses and nursing interventions. The Delphi technique accounts for the results depending on the level of experts; as there is no ideal number of judges, the group's composition varies according to the subject under study and criteria set by the researcher for the selection of these specialists. In the case of this study, the convenience sample was defined by 50 nurses, and the specificity of the rehabilitation area, the ICNP ${ }^{\infty}$ and studies that used experts for validation ${ }^{(6,10,12-13)}$ were considered.

The following criteria for the inclusion of experts were used: a) title of Master's of Nursing; b) title of Master's of Nursing with dissertation regarding content related to physical-motor rehabilitation, terminology, nursing process or nursing classifications; c) a research publication regarding physical-motor rehabilitation, terminology, nursing process or nursing classifications, with content relevant to the area; d) publication of an article on physical-motor rehabilitation, terminology, nursing process or nursing classifications in a reference journal; e) doctoral thesis regarding physical-motor rehabilitation, terminology, nursing process or nursing classifications; f) clinical practice of at least two years in physical-motor rehabilitation; g) relevant clinical practice certificate in physical-motor rehabilitation (specialist in nursing rehabilitation).

For the identification of nursing specialists who met the inclusion criteria, there was a survey accessing the Lattes 
Platform. Invitations were sent to 166 nurses who met the inclusion criteria, where 45 of them replied, of whom composed the study sample. The experts agreed and signed the Informed Consent and received a login and password to access the questionnaires via the internet.

To calculate the concordance index (CI) among judges, a Likert scale was used considering the following scales as agreement: "5=Extremely relevant", "4=Very relevant" and " 3 =Relevant"; and as disagreement: " 2 = Little relevant" and " $1=$ Not relevant." The calculation of CI was carried out from the formula $\mathrm{CI}=\mathrm{C} /(\mathrm{NC}+\mathrm{C})$, where $\mathrm{C}$ is the number of agreements and $\mathrm{NC}$ the number of disagreements ${ }^{(13)}$. Although the Delphi technique requires a concordance index $\geq 0.70$, it was decided to consider validated terms that reached a $\mathrm{CI} \geq 0.80$, as this is the value considered ideal in the literature.

89 definitions of terms that did not reach the $\mathrm{CI} \geq$ 0.80 in the first round were then revised based on sugges- tions submitted by participants and were sent to a second validation round, in which consensus among experts was reached $^{(12-13)}$.

At the end of the process, all 226 terms were validated.

\section{RESULTS}

A total of 825 terms of special nursing language for physical-motor rehabilitation were extracted from nursing registries of electronic patient records of adult patients admitted into the Rede Sarah Rehabilitation Hospital, Belo Horizonte-MG Unit, Brazil. It was found that 226 of those terms were still not included in the $\mathrm{ICNP}^{\circledR}$ 2.0. These terms, distributed by axis in Chart 1 , are the subject of this article.

Regarding the Focus axis, 45 terms were validated in the first round of the Delphi technique. The terms leisure and dry skin required a new round between the experts for their validations.

Chart 1 - Terms of special nursing language for physical-motor rehabilitation not listed in ICNP 2.0 , according to the classification axes.

\begin{tabular}{|c|c|}
\hline $\begin{array}{l}\text { FOCUS } \\
(47 \text { terms })\end{array}$ & $\begin{array}{l}\text { Allergy to iodine, environment, range of motion of joints, illiteracy, architectural barrier, bladder capacity, headache, } \\
\text { understanding, verbal communication, contracture, deformity, erection, emotional state, general state, stimulus, noxious } \\
\text { stimulus, eupnea, facial expression, exudate, hematuria, hypophonia, orthostatic hypotension, humor, fiber intake, } \\
\text { food intolerance, leisure, locomotion, malaise, multidrug-resistant microorganism, physical mobility, occupation, odor, } \\
\text { orgasm, cavus foot, varus foot, hydrated skin, friable skin, intact skin, blood pressure, rehabilitation process, quality of } \\
\text { life, retraining, bowel retraining, bladder retraining, oxygen saturation, signs of inflammation, granulation tissue. }\end{array}$ \\
\hline $\begin{array}{l}\text { JUDGEMENT } \\
(15 \text { terms) }\end{array}$ & $\begin{array}{l}\text { Calm, characteristic, difficult, discreet, stable, hydrated, unsatisfying, straightforward, interested, maximum, same level, } \\
\text { precarious, receptive, dry, satisfactory. }\end{array}$ \\
\hline $\begin{array}{l}\text { ACTION } \\
\text { (31 terms) }\end{array}$ & $\begin{array}{l}\text { Approach, admit, continue, schedule, heat, walking, disinfect, debride, differentiate, emphasize, evidence, promote, } \\
\text { hydrate, indicate, infuse, release, move around, modify, opt, optimize, prefer, welcome, recognize, repeat, respect, } \\
\text { return, submit, suspend, terminate, utilize, visit. }\end{array}$ \\
\hline $\begin{array}{l}\text { LOCATION } \\
\text { (25 terms) }\end{array}$ & $\begin{array}{l}\text { Shoulder joint, cistostomy, vertebral column, elbow, iliac crest, gastrectomy, jejunostomy, knee, lateral malleolus, } \\
\text { medial malleolus, lower limb, upper limb, shoulder, calf, patella, Fowler position, semi-Fowler position, hip, scapular } \\
\text { region, inguinal region, intergluteus region, sciatic region, trochanter region, anesthetic induction room, vesicostomy. }\end{array}$ \\
\hline $\begin{array}{l}\text { MEANS } \\
\text { (102 termos) }\end{array}$ & $\begin{array}{l}\text { Hidrophilic cotton, orthopedic cotton, synthetic cotton, antiemetic, anti-inflammatory, walker, adaptation device, } \\
\text { continuous passive motion machine, nursing assistant, support forearm cane, T cane, chair, surgical bed, tracheostomy } \\
\text { tube, catheter, analgesia catheter, nasal catheter, nasoenteric catheter, nasogastric catheter, indwelling catheter, } \\
\text { abdominal belt, transfer belt, petrolium jelly bandage, collagenase, cervical collar, air mattress, chest vest, moisturizer, } \\
\text { cryotherapy, dressing gauze, sterile hypoallergenic dressing tape, disinfectant, urination diary, case discussion, } \\
\text { interdisciplinary team, long handled bath brush, thickening, elastic band, digit-anal stimulus, crepe band, dietary } \\
\text { fiber, polyurethane film, speech therapist, cottony gauze, blood glucose, guidance group, hydrocolloid, hydrotherapy, } \\
\text { fluid control form, Credé maneuver, bladder emptying maneuvers, Fluid thrill maneuver, Valsalva maneuver, massage, } \\
\text { surgical supplies, oximetry monitor, axillary crutches, measures for seizure prevention, measures for deformity } \\
\text { prevention, measures for dysreflexia prevention, measures for infection prevention, measures for pressure ulcer } \\
\text { prevention, non-pharmacological measures, bladder monitor, nutritionist, lower limb orthosis, upper limb orthosis, } \\
\text { oxygen, insole, papain, research, research on multiresistant microorganism, psychologist, ointment, intestinal } \\
\text { preparation, reporting, meeting, hospital infection control service, pharmaceutical services, odontological services, } \\
\text { psychology service, swab, technical administration of enteral nutrition, bladder catheterization technique, bladder } \\
\text { self-catheterization technique, assisted catheterization technique, bladder emptying technique, Fowler positioning } \\
\text { technique, semi-Fowler positioning technique, self-care training technique, clean technique, cast technician, bladder } \\
\text { training technique, sling, digital rectal examination, pneumatic tourniquet, skin traction, transkeletal traction, } \\
\text { continence training, family training, xylocaine gel, toilet }\end{array}$ \\
\hline TIME (3 terms) & Weekend, time and period. \\
\hline CLIENT (3 terms) & wife and son. \\
\hline
\end{tabular}

In the Judgment axis, the two terms of discreet and bydrated required a second round for validation. The other terms were validated in the first validation round in relation to both the definitions as to the axis on which they were allocated.

On the Action axis, all the terms proposed were validated in the first validation round in relation to both the definitions as to the axis on which they were allocated.

Regarding the Location axis, 18 of the 25 proposed terms were validated in accordance with the first round of the validation process. 7 terms were validated in the second stage of the validation process.

102 new terms were identified for the Media axis. In the first round of the validation process, one term - digit-anal stimulus - did not achieve CI $\geq 0.80$ in relation to the axis in which it was allocated. Regarding the definitions proposed by the researchers, $26(25.49 \%)$ achieved CI $\geq 0.80$. Most experts sent suggestions and questions concerning the proposed definitions, so they had to be supplemented or amended. However, it can be highlighted that all definitions 
that were not validated in the first round were validated in the second round of the process, and the same occurred in relation to the term digit-anal stimulus, not previously validated for the axis on which it was allocated.

Among the 3 terms of the Time axis, the term period needed to go through a new round of the validation process for the definition, where it was validated. Similarly, among the 3 terms of the Client axis, the term son had to have its definition rewritten according to suggestions sent by experts, and validated in the second round of the process.

\section{DISCUSSION}

All terms identified as not contained in the ICNP $^{\infty}$ were validated by experts in relation to the definition and to the axis on which they were allocated after it had reached $\mathrm{CI} \geq 0.80$.

On the Focus axis between the validated terms very characteristic language used in the physical-motor rehabilitation may be observed. Terms such as range of motion of joints, architectural barrier, bladder capacity, contraction, deformity, mobility, physical mobility, hollow foot, varus foot, rehabilitation, quality of life, bowel retraining, and bladder retraining are well used in rehabilitation nursing practices $^{(2,5-6)}$.

On the Location axis, the terms like shoulder joint, spine, elbow, iliac crest, knee, lateral malleolus, medial malleolus, leg, arm, shoulder, calf, patella, hip, shoulder region, inguinal region, intergluteal region, sciatic region, and trochanteric region are related to body structures, where joint pain and skin lesions such as pressure ulcers, may occur ${ }^{(14-15)}$.

The Means axis was the one with the most validated terms, expressing all that the rehabilitation nurses use in their interventions to provide the rehabilitation of patients with motor and/or cognitive impairments and therefore some level of dependence. These patients require using adaptation resources to perform daily activities in order to minimize dependence or achieve independence (according to their motor and cognitive capabilities). As examples, the following can be mentioned: orthoses (used for limb placement, improving function or preventing deformities); bladder and bowel retraining techniques; control and prevention of complications such as autonomic dysreflexia, and pressure ulcer ${ }^{(2,6,14-15)}$.

This work enabled us to identify correlations between the language used by nurses and terms of $\mathrm{ICNP}^{\oplus}$. This result continuing the search in which it operates will trigger a process of building a subset of $\mathrm{ICNP}^{\circledR}$ concepts to physical-motor rehabilitation, and further improve this ranking system ${ }^{(2)}$.

One difficulty to be mentioned for this study was to obtain the number of experts that met the inclusion criteria for the sample and validate those not found in ICNP terms. The aim to achieve the minimum number of 50 was obtained but only with the participation of 45 experts, although the invitation was sent to 166 nurses. It is believed that the reduced participation of nurses may be related to factors such as the small number of nurses familiar with research conducted over the internet; lack of $\mathrm{ICNP}^{\oplus}$, stated in the expert's message as justification for refusal to participate; and also due to the extension of the data collection instrument, an apparent reason for the increasing number of losses as they progressed on issues available in it.

Another difficulty was found in the elaboration and validation of definitions for terms, as well as the definitions used in $\mathrm{ICNP}^{\oplus}$ which were considered very concise and slightly detailed, and did not satisfy most experts surveyed during the validation step. It should also be noted there is the need for improving the definitions of terms on the Means axis.

As a challenge to this study, the step of extracting terms can be mentioned as it was laborious and exhausting. It is believed that the use of software that searches nursing developments in electronic medical records for the most used terms identifying both the term and the number of times it has been used is of great value. Such a tool would facilitate the work of the researcher who would not need to analyze each evolution in detail, thereby reducing the time of this step and especially ensuring that no term was ignored during term extraction. However, it is important to understand that the use of software does not replace the researcher's work, since Pseudo-terminological expressions that are considered junk terminology would also need to be located, and one cannot ignore the context in which the terms appear in order to assign words which are related to the particular nursing language ${ }^{(16)}$.

When comparing the results obtained in this study with those of other studies using the same method and the $\mathrm{ICNP}^{\infty}$ as a reference terminology ${ }^{(17-18)}$, there is the fact of having used a large number of records, which allowed for the number of terms extracted to be quite high. In addition, it should be emphasized that this is the first study developed in nursing in physical-motor rehabilitation using the ICNP $^{\circledast} 2.0$ as a reference.

\section{CONCLUSION}

We sought to validate 226 terms not constant in the $\mathrm{ICNP}^{\oplus}$ and all were validated. The use of $\mathrm{ICNP}^{\oplus}$ Version 2.0 as reference terminology allowed cross mapping of the identified terms and later validation of these by the Delphi technique. This demonstrates that the use of $\mathrm{ICNP}^{\circledR}$ in the physical-motor rehabilitation field is possible, since it is designed to bring together the existing terms and develop new terms which allows for the systematic documentation of nursing activities using diagnostics, results and nursing interventions. This also demonstrates that the nursing staff of the studied institutions value and are incorporating the $\mathrm{ICNP}^{\infty}$ into their practices.

The validated terms in the $\mathrm{ICNP}^{\star}$ are part of a bank of terms that is currently being used to build a subset of concepts for nursing in physical-motor rehabilitation.

We emphasize the need for studies on the development of nursing language since these are fundamental in teaching, research, service and management in the area and contribute to the development and use of a standardized language for greater autonomy for nurses, which may reflect in better quality care to the patient. 
RESUMO

Objetivo: Validar os termos da linguagem especial de enfermagem em reabilitação físico-motora e mapeá-los com os termos da CIPE ${ }^{\circledR}$

2.0. Método: Pesquisa metodológica baseada em análise documental, com coleta e análise de termos de 1.425 prontuários. Resultados: Após o procedimento metodológico, obteve-se 825 termos, dos quais 226 ainda não constavam na CIPE 2.0 e que foram assim distribuídos: 47 no eixo foco; 15 no eixo julgamento; 31 no eixo ação; 25 no eixo localização; 102 no eixo meios; três no eixo tempo; e três no eixo cliente. Todos os termos não constantes na $\mathrm{CIPE}^{\mathbf{m}}$ foram validados pelos especialistas, havendo atingido índice de concordância $\geq 0,80$. Conclusão: $\mathrm{A} \mathrm{CIPE}^{\circledast}$ é aplicável e utilizada na assistência de enfermagem em reabilitação físico-motora.

\section{DESCRITORES}

Enfermagem em Reabilitação; Terminologia; Classificação; Estudos de Validação.

\section{RESUMEN}

Objetivo: Validar los términos del lenguaje especial de enfermería en rehabilitación físico-motora y mapearlos con los términos de la $\mathrm{CIPE}^{\circledast}$ 2.0. Método: Investigación metodológica basada en análisis documental, con recolección y análisis de términos de 1.425 fichas. Resultados: Después del procedimiento metodológico, fueron obtenidos 825 términos, de los que 226 todavía no figuraban en la CIPE 2.0 y que fueron distribuidos de la siguiente manera: 47 en el eje foco; 15 en el eje juicio; 31 en el eje acción; 25 en el eje ubicación; 102 en el eje medios; tres en el eje tiempo; y tres en el eje cliente. Todos los términos no obrantes en la CIPE ${ }^{\oplus}$ fueron validados por los expertos, habiendo alcanzado índice de concordancia $\geq 0,80$. Conclusión: La CIPE ${ }^{\circledast}$ es aplicable y utilizada en la asistencia de enfermería en rehabilitación físico-motora.

\section{DESCRIPTORES}

Enfermería en Rehabilitación; Terminología; Clasificación; Estudios de Validación.

\section{REFERENCES}

1. Carvalho EC, Cruz DALM, Herdman TH. Contribuição das linguagens padronizadas para a produção do conhecimento, raciocínio clínico e prática clínica da Enfermagem. Rev. bras. enferm. [serial on the Internet]. 2013 Sep [cited 2014 Sep 08] ; 66 ( spe ): 134-141. Available from: http://www.scielo.br/scielo.php?script=sci_arttext\&pid=S0034-71672013000700017\&lng=en. http://dx.doi.org/10.1590/ S0034-71672013000700017.

2. Andrade LT, Araújo EG, Andrade KRP, Souza DRP, Garcia TR, Chianca TCM. Disreflexia autonômica e intervenções de enfermagem para pacientes com lesão medular. Rev. esc. enferm. USP [serial on the Internet]. 2013 Feb [cited 2014 Sep 08] ; 47( 1 ): 93-100. Available from: http://www.scielo.br/scielo.php?script=sci_arttext\&pid=S0080-62342013000100012\&lng=en. http://dx.doi.org/10.1590/S008062342013000100012 .

3. Garcia TR, Nóbrega MML. Classificação Internacional para a Prática de Enfermagem: inserção brasileira no projeto do Conselho Internacional de Enfermeiras. Acta paul. enferm. [periódico na Internet]. 2009 [citado 2014 Set 08]; 22( spe ): 875-879. Disponível em: http://www. scielo.br/scielo.php?script=sci_arttext\&pid=S0103-21002009000700006\&lng=pt. http://dx.doi.org/10.1590/S0103-21002009000700006.

4. Garcia TR, Nóbrega MML. A terminologia CIPE $®$ e a participação do Centro CIPE $®$ brasileiro em seu desenvolvimento e disseminação. Rev. bras. enferm. [serial on the Internet]. 2013 Sep [cited 2014 Sep 08] ; 66 ( spe ): 142-150. Available from: http://www.scielo.br/scielo. php?script=sci_arttext\&pid=S0034-71672013000700018\&lng=en. http://dx.doi.org/10.1590/S0034-71672013000700018.

5. Andrade LT, Araújo EG, Andrade KRP, Soares DM, Chianca TCM. Papel da enfermagem na reabilitação física. Rev. bras. enferm. [periódico na Internet]. 2010 Dez [citado 2014 Set 08] ; 63( 6 ): 1056-1060. Disponível em: http://www.scielo.br/scielo.php?script=sci_ arttext\&pid=S0034-71672010000600029\&lng=pt. http://dx.doi.org/10.1590/S0034-71672010000600029.

6. Andrade LT, Chianca TCM. Validação de intervenções de enfermagem para pacientes com lesão medular e mobilidade física prejudicada Rev. bras. enferm. [periódico na Internet]. 2013 Out [citado 2014 Set 08] ; 66 ( 5 ): 688-693. Disponível em: http://www.scielo.br/scielo. php?script=sci_arttext\&pid=S0034-71672013000500008\&lng=pt. http://dx.doi.org/10.1590/S0034-71672013000500008.

7. Brasil. Resolução ${ }^{\circ} 466$ de 12 de dezembro de 2012. Publicada no DOU no 12 - quinta-feira, 13 de junho de 2013 - Seção 1 - Página 59.

8. Pavel S, Nolet D. Manual de Terminologia. Canadá: Public Words and Govermment Services; 2002. 151 p.

9. Tannure MC, Chianca TCM, Garcia TR. Construção de um banco de termos da linguagem especial de enfermagem. Rev Eletr Enferm [Internet]. 2009 [citado 2014 Set. 8];11(4):1026- 30. Disponível em: http://www.fen.ufg.br/revista/v11/n4/v11n4a29.htm

10. Clares JWB, Freitas MC, Guedes MVC, Nobrega MML da. Construção de subconjuntos terminológicos: contribuições a pratica clinica do enfermeiro. Rev. esc. enferm. USP [serial on the Internet]. 2013 Aug [cited 2014 Sep 12] ; 47( 4 ): 965-970. Available from: http://www.scielo.br/scielo.php?script=sci_arttext\&pid=S0080-62342013000400965\&lng=en. http://dx.doi.org/10.1590/S0080-623420130000400027 .

11. Nielsen GH, Mortensen RA. The architecture of ICNP: time of outcomes - Part. I. International Nursing Review; 1997; 44[S.I.]:182-8.

12. Chianca TCM, Lima APS, Salgado PO. Diagnósticos de enfermagem identificados em pacientes internados em Unidade de Terapia Intensiva Adulto. Rev. esc. enferm. USP [serial on the Internet]. 2012 Oct [cited 2014 Sep 12] ; 46( 5 ): 1102-1108. Available from: http://www. scielo.br/scielo.php?script=sci_arttext\&pid=S0080-62342012000500010\&lng=en. http://dx.doi.org/10.1590/S0080-62342012000500010.

13. Cubas MR, Brondani AM, Malucelli A. Diagnósticos e resultados de enfermagem relacionados aos termos do sistema circulatório - ClPE® representados em uma ontologia. Rev. esc. enferm. USP [serial on the Internet]. 2013 Oct [cited 2014 Sep 12] ; 47( 5 ): $1068-1075$. Available from: http://www.scielo.br/scielo.php?script=sci_arttext\&pid=S0080-62342013000501068\&lng=en. http://dx.doi.org/10.1590/ S0080-623420130000500009.

14. Vidal AA, Padula MPC. A Enfermagem em reabilitação física como tema de Trabalhos de Conclusão de Curso (TCC) de Graduação em Enfermagem. Arq Med Hosp Fac Cienc Med Santa Casa São Paulo. 2012; 57: 97-102.

15. Kodama CM, Spuras MV, Padula MPC. Cuidados prestados pelos enfermeiros aos pacientes de reabilitação. Arq Med Hosp Fac Cienc Med Santa Casa São Paulo. 2009; 54(3): 100-6. 
16. Silva DL, Souza R, Almeida MB. Ontologias e vocabulários controlados: comparação de metodologias para construção. Ci. Inf [serial on the Internet]. $2008 \mathrm{dez}$ [cited 2014 Sep 12]; 37 (3): 60-65. Available from: <http://www.scielo.br/scielo.php?script=sci_arttext\&pid=S0100$19652008000300005 \&$ Ing=pt\&nrm=iso $>$. http://dx.doi.org/10.1590/S0100-19652008000300005.

17. Bittencourt, G.K.G.D., Nóbrega, M.M.L. (2006) Confirmação de significado para a prática profissional de termos atribuídos a ações de enfermagem: estudo descritivo. [Meaning for the professional practice of terms attributed to actions of nursing: a descriptive study]. Online Brazilian Journal of Nursing, 5, 1-9. Available at: http://www.objnursing.uff.br/index.php/nursing/article/view/308/65 (accessed on 2012 Jun 13).

18. Trigueiro EV et al. (2009) Construção do banco de termos da linguagem especial de enfermagem de uma Unidade de Terapia Intensiva com base no modelo de sete eixos da CIPE ${ }^{\circledR}$ Versão 1.0. [Construction of a bank of terms of the special nursing language in an adult intensive care unit based on the ICNP ${ }^{\circledR}$ seven-axis model]. Revista de Enfermagem UFPE on line. Available at: http://www.revista.ufpe.br/ revistaenfermagem/index.php/revista/article/download/156/2861. (accessed on 2011 jul 17)

\section{Acknowledgement:}

To Laboratório de Computação Científica (LCC) - Centro Nacional de Processamento de Alto Desempenho, Universidade Federal de Minas Gerais, for the creation of the on-line data collection instrument. 